\title{
The effect of Piper laetispicum extract (EAE- P) during chronic unpredictable mild stress based on interrelationship of inflammatory cytokines, apoptosis cytokines and neurotrophin in the hippocampus
}

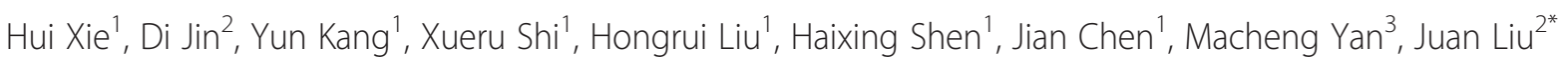
and ShengLi Pan ${ }^{1 *}$

\begin{abstract}
Backgroud: The Piper laetispicum C.DC. (Piperaceae) is a traditionally used herb in China for invigorating circulation and reducing stasis, detumescence and analgesia, which is distributed in the southern part of China and the southeastern part of Asia. Previous studies demonstrated that the ethyl acetate extract (EAE-P) of P. laetispicum possesses a significant antidepressant-like effect at doses higher than $60 \mathrm{mg} / \mathrm{kg}$ in Kunming (KM) mice, and this effect was not due to an increase in locomotive activity.

Methods: To research this mechanism, in the present study, the chronic unpredictable mild stress (CUMS) model in Sprague-Dawley rats was used to further elucidate behavioral changes and corresponding changes in inflammatory cytokines (TNF-a, IL-6, IL-10), apoptosis cytokines (P53, Bax, BCl2, caspase-3) and neurotrophin (BDNF) in the hippocampus of EAE-P treatment animals.

Results and conclusions: The results suggest that EAE-P is beneficial to the behavioral outcome of the CUMS model animals, and decreased amounts of inflammatory cytokine IL-6 contributed to the antidepressant-like activation of EAE-P in every dosage group $(15,30,60 \mathrm{mg} / \mathrm{kg})$. In the low dosage group, down-regulated apoptosis cytokine p53 is associated with EAE-P effect, but it is inflammatory cytokine TNF-a that is related to the effect of EAE-P in the high dosage group. Meanwhile, the P53-dependent antiapoptotic effect of EAE-P may not be through $\mathrm{Bcl}-2$ and Bax modulation. Furthermore, EAE-P showed up-regulated expression of brain-derived neurotrophic factor (BDNF) mRNA and down-regulated apoptosis cytokine caspase-3 mRNA, which was the same change tendency as with Fluoxetine.
\end{abstract}

Keywords: Piper laetispicum, Piperaceae, Ethyl acetate extract, Antidepressant, Hippocampus

\section{Background}

Depression is one of the most burdensome diseases, usually associated with acute and persistent symptoms leading to life quality impairment [1]. Extensive studies of herbal medicines potentially useful in the treatment of depression have been conducted. Many of them have

\footnotetext{
* Correspondence: liujuan1949@163.com; slpan@shmu.edu.cn ${ }^{2}$ Department of Pharmacognosy, College of Pharmacy, Jiamusi University, Jiamusi 154007, China

'School of Pharmacy, Fudan University, Shanghai 201203, China Full list of author information is available at the end of the article
}

been shown to have high efficacy and safety, such as Hypericum perforatum (St. John's wort), Panax ginseng, Piper methysticum, Paullinia cupana var. sorbilis (Guaraná) and Chaihu-Shugan-San, etc. [2-6].

The Piper laetispicum C.DC. (Piperaceae) is an endemic, climbing, glabrous plant distributed in the southern part of China and the southeastern part of Asia where it is popularly known as Xiao Chang-feng, Shan $\mathrm{Hu}$-jiao, and Ye Hu-jiao. It is traditionally used for invigorating circulation and reducing stasis, detumescence and analgesia in China [7]. Laetispicine

\section{()


(N-isobutyl- (3,4-methylendioxyphenyl)-2E, 4E, 9Eundecatrienoamide) was previously isolated and reported for its exertion of antidepressant activity and antinociceptive effects in mice [8]. We further demonstrated that the ethyl acetate extract of P. laetispicum (EAE-P) possesses a significantly antidepressantlike effect at doses higher than $60 \mathrm{mg} / \mathrm{kg}$ in $\mathrm{KM}$ mice and proved that this was not due to an increase in locomotive activity [9].

In this present study, the chronic unpredictable mild stress (CUMS) model in Sprague -Dawley rats was used to further elucidate the antidepressant-like effects and mechanism of EAE-P. CUMS, the most promising rodent model for depression, is further supported and widely used for preclinical testing and screening of antidepressants [10-12]. In the CUMS model, animals are subjected to a variety of mild stressors, which mimic chronic stressful life events, presented intermittently for prolonged periods of time, and result in a behavioral deficit anhedonia, a core symptom of human depression [10]. Furthermore, since the hippocampus is critical for stress, learning and memory processes in depression and in the antidepressant response to pharmaco therapy [13], the corresponding changes in inflammatory cytokines (TNF- $\alpha$, IL-6, IL-10), apoptosis cytokines (P53, $\mathrm{Bax}, \mathrm{Bcl} 2$, caspase-3) and neurotrophin (BDNF) in the hippocampus were evaluated along with the behavioral evaluation.

\section{Methods}

\section{Animals and grouping}

Adult male Sprague-Dawley rats weighing between 180 and $200 \mathrm{~g}$ were purchased from the Department of Experimental Animal Center of Fudan University. Rats were housed under a normal $12 \mathrm{~h}$ light/dark cycle with lights on at 7 a.m. Tap water and standard food pellets were available ad libitum. Ambient temperature and relative humidity were maintained at $22-25{ }^{\circ} \mathrm{C}$ and $55 \pm 10 \%$, respectively. Prior to the test procedure, rats were acclimatized the laboratory for seven days. The experimental procedures were conducted in compliance with the National Institutes of Health Guide for Care and Use of the laboratory animals and were approved by the Local Bioethics Committee (School of Pharmacy, Fudan University, China; document number: SYXK2007-002). Every effort was made to minimize the number and suffering of the animals used.

After a seven-day environmental adaptation, 54 animals were randomly divided into six groups: nonstressed control group (abbreviation: Control); $20 \mathrm{mg} / \mathrm{kg}$ fluoxetine group (abbreviation: Fluoxetine); model group (abbreviation: Model); $15 \mathrm{mg} / \mathrm{kg}$ EAE-P group (abbreviation: $15 \mathrm{mg} / \mathrm{kg}$ ); $30 \mathrm{mg} / \mathrm{kg}$ EAE-P group (abbreviation: $30 \mathrm{mg} / \mathrm{kg}$ ); and $60 \mathrm{mg} / \mathrm{kg}$ EAE-P group (abbreviation:
$60 \mathrm{mg} / \mathrm{kg}$ ). Each group's baseline of $1 \%$ sucrose preference, motor activity, body weight, and food consumption were measured. There were no significant differences amongst the groups. The results are shown in Table 1 . The control rats were kept undisturbed in their home cages during the entire period of treatment, receiving only ordinary facility care with daily support of food and water, except for the sucrose intake test. The animals in other groups were fed separately in single cages.

\section{Chronic unpredictable mild stress (CUMS) mode}

The chronic unpredictable mild stress protocol was adapted from Gamaro et al. [14]. The eight-week CUMS paradigm's first 28 days are shown in Table 2; the following days repeat it. One of the stressors was used each day and only interrupted by the sucrose preference test. This paradigm was used for the animals in the Fluoxetine, Model, $15 \mathrm{mg} / \mathrm{kg}$ group, $30 \mathrm{mg} / \mathrm{kg}$ group and $60 \mathrm{mg} / \mathrm{kg}$ group.

\section{Plant material}

The stems of P. laetispicum were collected in 2006, from Hainan Province, China. The plant was identified by Professor Sheng-li Pan, School of Pharmacy, Fudan University, where a voucher specimen (No.060812) of the plant material has been deposited for further reference.

Before use, the dried stems of $P$. laetispicum were stored at $-20{ }^{\circ} \mathrm{C}$ in freezer.

\section{Extract and drugs}

The dried stems of P. laetispicum (20 kg) were powdered and percolated with $95 \%$ EtOH (Ethyl alcohol), and the solution was concentrated under reduced pressure to give crude extract $(1510 \mathrm{~g})$. The ethyl acetate extract (EAE-P) was obtained following the methods published by our group [9] [15]. The HPLC profile was the same with Xie et al. [9]. And the content of four major components in EAE-P - Chingchingenamide $(1.24 \mathrm{mg} / \mathrm{g})$, Laetispiamide A (12.67 mg/g), Laetispiamide B (1.25 mg/g) and Laetispicine $(9.65 \mathrm{mg} / \mathrm{g})$ - were approached.

The EAE-P was kept refrigerated at $+4{ }^{\circ} \mathrm{C}$ and suspended in a solution of $2 \%$ Tween- 80 in saline by sonication with an ultrasonic cleaner (SK2200H, Shanghai KUDOS Ultrasonics instrument Co., Ltd (Shanghai, China)) less than $60{ }^{\circ} \mathrm{C}$. The $2 \%$ Tween-80 in saline also served as a solution control. Pharmacological screenings were performed and administered in doses of 15, 30 and $60 \mathrm{mg} / \mathrm{kg}$ body weight. All dosages were expressed as milligrams per kilogram body weight.

Fluoxetine- $\mathrm{HCl}$, which purity was $98 \%$, was used in a concentration of $20 \mathrm{mg} / \mathrm{kg}$ body weight and prepared fresh on the day of administration in solution (2\% Tween-80 suspension in saline). 
Table 1 The baseline of sucrose solution consumption, motor activity, body weight and food consumption

\begin{tabular}{|c|c|c|c|c|c|c|}
\hline \multirow[t]{2}{*}{ Groups } & \multirow{2}{*}{$\begin{array}{l}1 \% \text { Sucrose solution } \\
\text { consumption (\%) }\end{array}$} & \multicolumn{3}{|l|}{ Motor activity } & \multirow{2}{*}{$\begin{array}{l}\text { Body weight } \\
\text { (gram) }\end{array}$} & \multirow{2}{*}{$\begin{array}{l}\text { Food consumptior } \\
\text { (gram) }\end{array}$} \\
\hline & & $\begin{array}{l}\text { Score locomotion } \\
\text { (times) }\end{array}$ & $\begin{array}{l}\text { Rearing frequencies } \\
\text { (times) }\end{array}$ & $\begin{array}{l}\text { Grooming time } \\
\text { (seconds) }\end{array}$ & & \\
\hline control & $76.44 \pm 2.19$ & $137.78 \pm 11.28$ & $22.11 \pm 2.71$ & $10.96 \pm 2.02$ & $263.17 \pm 4.45$ & $27.90 \pm 1.31$ \\
\hline Fluoxetine & $77.46 \pm 2.24$ & $135.81 \pm 7.64$ & $26.00 \pm 2.10$ & $12.19 \pm 4.01$ & $266.83 \pm 3.18$ & $28.20 \pm 1.72$ \\
\hline model & $77.37 \pm 2.29$ & $120.72 \pm 8.97$ & $23.00 \pm 2.39$ & $13.88 \pm 1.97$ & $256.08 \pm 6.36$ & $33.00 \pm 0.47$ \\
\hline 15 mg/kg & $78.68 \pm 2.48$ & $138.69 \pm 11.00$ & $26.14 \pm 3.62$ & $10.84 \pm 1.85$ & $258.14 \pm 7.74$ & $31.74 \pm 1.17$ \\
\hline 30 mg/kg & $76.70 \pm 3.90$ & $119.42 \pm 17.12$ & $20.17 \pm 3.11$ & $16.28 \pm 5.23$ & $251.35 \pm 4.88$ & $30.86 \pm 1.44$ \\
\hline 60 mg/kg & $78.40 \pm 3.47$ & $135.19 \pm 8.54$ & $28.29 \pm 4.17$ & $17.58 \pm 1.65$ & $265.27 \pm 3.51$ & $28.17 \pm 1.65$ \\
\hline
\end{tabular}

Data are expressed as mean \pm S.E.M. $(n=8-9)$. The statistical analysis was performed by analysis of variance (ANOVA) followed by Bonferroni's test

$95 \%$ EtOH, ethyl acetate, Tween-80 were purchased from Sinopharm Chemical Reagent Co., Ltd (Shanghai, China). Saline was from Shanghai Zhongxi Pharmaceutical Co., Ltd (Shanghai, China). Fluoxetine-HCl was from Cyber- Hubei Cyber Pharmaceutical Co., Ltd. (Wuhan, China).

\section{Sucrose preference test}

A sucrose preference test was employed in order to determine anhedonia, one of the core symptoms of major depression in humans [11]. After environmental adaptation, rats were trained to consume $1 \%(\mathrm{w} / \mathrm{v})$ sucrose solution. Then the rats were simultaneously presented with $1 \%$ sucrose solution and fresh water for $1 \mathrm{~h}$ after $23 \mathrm{~h}$ of food and water deprivation, as reported previously [16]. Sucrose preference (SP) was calculated according to the following formula: $\mathrm{SP}=$ sucrose intake/ (sucrose intake + water intake) $\times 100 \%$. The sucrose preference test was performed each week and measured between 9 a.m. and 10 a.m. During this period, the animals were stressed daily, and the food and water were removed the night before the test.

\section{Open field test}

The open field test method used in the present study was similar to that described previously by Kim [6]. The apparatus was a square arena (diameter: $80 \mathrm{~cm}$; height: $40 \mathrm{~cm}$ ) with a light source of $120 \mathrm{~lx}$, which was demarcated into 25 equal areas. The score locomotion (number of line crossings), rearing frequencies (number of times an animal stood on its hind legs) and grooming time were recorded.

\section{Food utilization rate}

Intake of food was measured by weighing the remaining food between 9 a.m. and 10 a.m. every day. Body weight was recorded at the end of each week. The food utilization rate (FUR) was calculated according to the following formula: FUR = body weight gain per week (g)/ food-intake $(\mathrm{g})$ per week $\times 100 \%[17,18]$.

\section{Blood collection and serum cytokine assay}

After the last treatment of drugs, approximately $5 \mathrm{~mL}$ of blood was collected from the rat tail. Serum cytokine levels of BDNF were measured using the Rat

Table 2 The unpredictable chronic mild stress protocol

\begin{tabular}{|c|c|c|c|}
\hline 1 & Light during the night & 15 & $24 \mathrm{~h}$ of damp sawdust \\
\hline 2 & 5 min swimming at $4{ }^{\circ} \mathrm{C}$ & 16 & 15 min Shaker rocking 1 time/second \\
\hline 3 & $24 \mathrm{~h}$ of food deprivation & 17 & Light during the night \\
\hline 4 & $24 \mathrm{~h}$ of water deprivation & 18 & 24 h of water deprivation \\
\hline 5 & Light during the night & 19 & 1 min clipping tail \\
\hline 6 & 15 min shaker rocking 1 time/second & 20 & $2 \mathrm{~h}$ of restraint \\
\hline 7 & $24 \mathrm{~h}$ of food deprivation & 21 & 5 min swimming at $45^{\circ} \mathrm{C}$ \\
\hline 8 & 1 min clipping tail & 22 & $2 \mathrm{~h}$ of restraint \\
\hline 9 & $2 \mathrm{~h}$ of restraint & 23 & 1 min clipping tail \\
\hline 10 & 5 min swimming at $45^{\circ} \mathrm{C}$ & 24 & $24 \mathrm{~h}$ of damp sawdust \\
\hline 11 & 5 min swimming at $4{ }^{\circ} \mathrm{C}$ & 25 & $24 \mathrm{~h}$ of water deprivation \\
\hline 12 & 5 min swimming at $45^{\circ} \mathrm{C}$ & 26 & 5 min swimming at $4{ }^{\circ} \mathrm{C}$ \\
\hline 13 & 15 min shaker rocking 1 time/second & 27 & 24 h of damp sawdust \\
\hline 14 & $24 \mathrm{~h}$ of food deprivation & 28 & 5 min swimming at $4{ }^{\circ} \mathrm{C}$ \\
\hline
\end{tabular}


BDNF (Brain-Derived Neurotrophic Factor) ELISA Kit (Xitang, Shanghai Xitang Technology Co., Ltd, Shanghai, China) and analyzed using Multiskan MK3 (Thermo, Thermo Scientific, USA). Serum from each animal was assayed in duplicate per manufacturer's instructions.

\section{Real-time PCR}

Total RNA was extracted from hippocampi using TRIzol reagent and assessed for quantity and integrity using agarose gel electrophoresis and Eppendorf Biophotometer Plus (Eppendorf, New Brunswick, CA). Total mRNA $(1 \mu \mathrm{g})$ was reverse transcribed using PrimeScript ${ }^{\circledR} 1$-st Strand cDNA Synthesis Kit (TaKaRa, TAKARA Biotechnology (Dalian) Co., Ltd., Dalian, China) according to the manufacturer's manual.

Real-time PCR was performed on a fluorescence ration PCR instrument (BioNeer, Korea) using SYBR ${ }^{@}$ Premix Ex TaqTM II (TaKaRa, TAKARA Biotechnology (Dalian) Co., Ltd., Dalian, China). Target cDNA (TNF- $\alpha$, IL-6, IL-10, P53, BDNF, Bax, Bcl2, caspase-3) and endogenous control cDNA (actin) were amplified under the following conditions: $94{ }^{\circ} \mathrm{C}$ for $4 \mathrm{~min}, 35$ cycles at $94{ }^{\circ} \mathrm{C}$ for $20 \mathrm{~s}, 60{ }^{\circ} \mathrm{C}$ for $30 \mathrm{~s}$ and $72{ }^{\circ} \mathrm{C}$ for $30 \mathrm{~s}$. Relative quantitative (RQ) measurements of target gene levels were performed using the $\Delta \Delta \mathrm{Ct}$ method, where $\mathrm{Ct}$ is the threshold concentration [19]. The oligonucleotides used as primers are shown in Table 3.

\section{Western blot analysis}

For immunoblotting studies, hippocampal total protein was prepared by homogenization in lysis buffer containing $20 \mathrm{mM}$ Tris- $\mathrm{HCl}$ (pH 7.5), $150 \mathrm{mM} \mathrm{NaCl}$, $1 \mathrm{mM}$ EDTA, and $0.1 \%$ sodium dodecyl-sulfate (SDS). The proteins were purified, resolved and electrotransferred as reported previously [20]. All blots were re-probed with $\beta$-actin antibody (1:4000 dilution, mouse monoclonal, Sigma, purchased from Sinopharm Chemical Reagent Co., Ltd (Shanghai, China)) as an internal control. Immunoreactive bands were revealed by an enhanced chemiluminescence kit (ECL Amersham from GE Healthcare) and detected using X-ray films. The immunoblot films were scanned, and the digitalized images analyzed with Gel-Pro Analyzer software.

\section{Statistical analysis of data}

SPSS 15.0 was used for statistical analysis. Statistical significance between groups was performed by the application of analysis of variance ANOVA followed by Bonferroni's test. Data obtained were expressed as mean \pm standard error of the mean (S.E.M.). And P-values less than $0.05(p<0.05)$ were used as the significant level.

\section{Results and discussion}

\section{Effects of EAE-P on Behavioral Tests in the CUMS-treated} rats

The sucrose preference test was used to determine the animals' depressive state [11]. As shown in Fig. 1, the baseline sucrose preference index was 76.44-78.68\% (the numerical value display in Table 1). At the end of the third week, significant differences were observed between the control and model groups, which are the key indicator of successful implementation of the CUMS model. After the administration of different concentrations of EAE-P for five weeks, the sucrose preferences of the $15 \mathrm{mg} / \mathrm{kg}$, $30 \mathrm{mg} / \mathrm{kg}$ and $60 \mathrm{mg} / \mathrm{kg}$ groups were significantly higher than the model group $(\mathrm{p}<0.001)$. Meanwhile, treatment with Fluoxetine also significantly increased the percentage of sucrose consumption as compared to the control group ( $\mathrm{p}<0.001$ ), but this result needed six weeks of administration, one week longer than EAE-P.

Nonetheless, at the second week of Fluoxetine and the fifth week of $30 \mathrm{mg} / \mathrm{kg}$ EAE-P, the sucrose preference was significantly lower than the control group $(\mathrm{p}<0.05$ and $\mathrm{p}<0.001)$. This was very interesting.

The Open Field Test (OFT) is commonly used to investigate locomotor activity, exploratory and depressivelike behaviors in experimental animals [21]. The times of score locomotion and rearing frequencies, and the seconds of grooming time were measured during the OFT at the end of the CUMS procedure. These details are shown in Table 4. After eight weeks, no significant differences were discovered. This suggests the EAE-P given in a subchronic treatment regime was beneficial for the behavioral outcome, which was not due to an increase in locomotive activity.

For the Food Utilization Rate (FUR), as shown in Fig. 2, there were no significant differences amongst the groups during the first stressful week of the CUMS procedure. During the second week, the FUR of the model group and all of the EAE-P groups increased, and demonstrated significant differences compared to the control group $(\mathrm{p}<0.001)$. At the end of the third week, the FUR was close to the control group, except for the Fluoxetine group, which was significantly higher than the model and control groups $(\mathrm{p}<0.001)$. In the following week, the FUR of the $30 \mathrm{mg} / \mathrm{kg}$ group abruptly increased (compared to the other groups ( $\mathrm{p}<$ 0.001)). At the next week (the fifth week), the FUR of the control group was unexpectedly lower than the model $(\mathrm{p}<0.01)$ and $15 \mathrm{mg} / \mathrm{kg}(\mathrm{p}<0.05)$ groups. In the last three weeks, the FUR of the control group was significantly higher than the model and all of the EAE-P groups.

Meanwhile, the Fluoxetine group was significantly lower than the model, $15 \mathrm{mg} / \mathrm{kg}$ or $60 \mathrm{mg} / \mathrm{kg}$ EAE-P groups at the second and the last three weeks, and significantly lower than the $30 \mathrm{mg} / \mathrm{kg}$ group at the fourth and seventh week. The details of comparison between 
Table 3 The oligonucleotides used as primers

\begin{tabular}{|c|c|c|c|}
\hline Gene & Primer name & Sequence of primer & Target length \\
\hline \multirow[t]{2}{*}{ tnfa } & rTNFaF & CTTCTCATTCCTGCTCGTGG & $140 \mathrm{bp}$ \\
\hline & rTNFaR & ATCTGAGTGTGAGGGTCTGGG & \\
\hline \multirow[t]{2}{*}{ IL-6 } & rlL6F & AAGCCAGAGTCATTCAGAGCAA & $160 \mathrm{bp}$ \\
\hline & rlL6R & TGGATGGTCTTGGTCCTTAGC & \\
\hline \multirow[t]{2}{*}{ IL-10 } & rlL10F & CCTGGTAGAAGTGATGCCCC & $163 \mathrm{bp}$ \\
\hline & rlL10R & ATTCTTCACCTGCTCCACTGC & \\
\hline \multirow[t]{2}{*}{ AlF } & rAIFF & CTGAGAAAGGAAATATGGGGAA & $138 \mathrm{bp}$ \\
\hline & rAIFR & TGAGTAACTTGCCACCGCTG & \\
\hline \multirow[t]{2}{*}{ P53 } & rP53F & GGAAGGAAATCCGTATGCTGA & $177 \mathrm{bp}$ \\
\hline & rP53R & GTGATGATGGTAAGGATGGGC & \\
\hline \multirow[t]{2}{*}{$\operatorname{Bax}$} & rBaxF & CCCGAGAGGTCTTCTTCCG & $167 \mathrm{bp}$ \\
\hline & rBaxR & GAAGTCCAGTGTCCAGCCCA & \\
\hline \multirow[t]{2}{*}{ caspase-3 } & rcaspase-3 F & CGAAACTCTTCATCATTCAGGC & $129 \mathrm{bp}$ \\
\hline & rcaspase-3R & AGTAAGCATACAGGAAGTCGGC & \\
\hline \multirow[t]{2}{*}{ Bdnf } & rBdnfF & CAGCGGCAGATAAAAAGACTG & $187 \mathrm{bp}$ \\
\hline & rBdnfR & GTAGTTCGGCATTGCGAGTTC & \\
\hline \multirow[t]{2}{*}{ TrkB } & rTrkBF & TATGAAGACTGGACCACGCC & $167 \mathrm{bp}$ \\
\hline & rTrkBR & AGAAGCAGCATCACCAGCAG & \\
\hline \multirow[t]{2}{*}{ CREB } & rCREBF & AGACCACTGATGGACAGCAGAT & $150 \mathrm{bp}$ \\
\hline & rCREBR & TAGGAAGTGCTGGGGAGGAC & \\
\hline \multirow[t]{2}{*}{$\mathrm{BCl}-2$} & $\mathrm{rBCl}-2 \mathrm{~F}$ & GTGAACTGGGGGAGGATTGT & $167 \mathrm{bp}$ \\
\hline & $\mathrm{rBCl}-2 \mathrm{R}$ & GCATCCCAGCCTCCGTTA & \\
\hline \multirow[t]{2}{*}{ actin } & rat $\operatorname{actin} f$ & CCCATCTATGAGGGTTACGC & $150 \mathrm{bp}$ \\
\hline & rat actin $r$ & TTTAATGTCACGCACGATTTC & \\
\hline
\end{tabular}
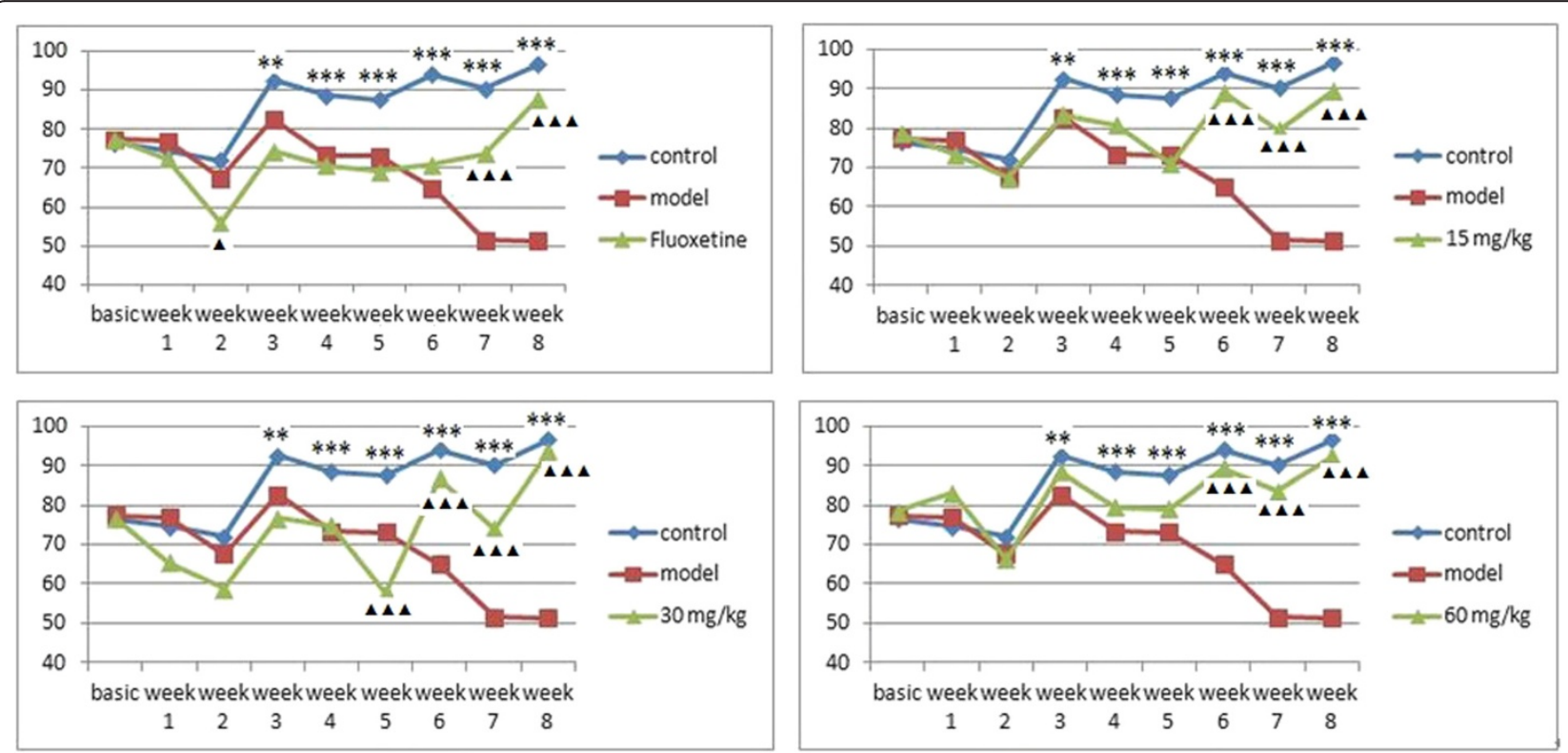

Fig. 1 Effects of EAE-P on sucrose preference in the CUMS-treated rats. Results are expressed as mean \pm S.E.M. $(n=7-9)$. Statistical analysis was performed by analysis of variance (ANOVA) followed by Bonferroni's test. $\boldsymbol{A} P<0.05, \boldsymbol{\Delta} \boldsymbol{\Delta} \mathrm{P}<0.01$, ${ }^{* *} \mathrm{P}<0.01, \boldsymbol{\Delta} \boldsymbol{\Delta} \boldsymbol{\Delta} \mathrm{P}<0.001$ and ${ }^{* *} \mathrm{P}<0.001$ compared with model 
Table 4 Effects of EAE-P on the open field parameters recorded for 6 min in rats

\begin{tabular}{|c|c|c|c|c|c|c|}
\hline \multirow[t]{2}{*}{ Groups } & \multicolumn{2}{|c|}{ Score Locomotion(times) } & \multicolumn{2}{|c|}{ Rearing Frequencies(times) } & \multicolumn{2}{|c|}{ Grooming Time(seconds) } \\
\hline & Begin & After & Begin & After & Begin & After \\
\hline control & $137.78 \pm 11.28$ & $121.00 \pm 12.41$ & $22.11 \pm 2.71$ & $16.78 \pm 2.11$ & $10.96 \pm 2.02$ & $18.83 \pm 5.04$ \\
\hline Fluoxetine & $135.81 \pm 7.64$ & $97.75 \pm 16.71$ & $26.00 \pm 2.10$ & $13.50 \pm 3.15$ & $12.19 \pm 4.01$ & $40.47 \pm 8.82$ \\
\hline model & $120.72 \pm 8.97$ & $100.33 \pm 14.18$ & $23.00 \pm 2.39$ & $25.33 \pm 4.37$ & $13.88 \pm 1.97$ & $21.60 \pm 5.55$ \\
\hline $15 \mathrm{mg} / \mathrm{kg}$ & $138.69 \pm 11.00$ & $126.50 \pm 15.02$ & $26.14 \pm 3.62$ & $17.88 \pm 2.96$ & $10.84 \pm 1.85$ & $14.67 \pm 6.12$ \\
\hline $30 \mathrm{mg} / \mathrm{kg}$ & $119.42 \pm 17.12$ & $99.71 \pm 13.20$ & $20.17 \pm 3.11$ & $20.71 \pm 2.62$ & $16.28 \pm 5.23$ & $25.99 \pm 5.74$ \\
\hline $60 \mathrm{mg} / \mathrm{kg}$ & $135.19 \pm 8.54$ & $128.75 \pm 16.07$ & $28.29 \pm 4.17$ & $24.50 \pm 3.18$ & $17.58 \pm 1.65$ & $21.33 \pm 4.15$ \\
\hline
\end{tabular}

Data are expressed as mean \pm S.E.M. $(n=8-9)$. The statistical analysis was performed by analysis of variance (ANOVA) followed by Bonferroni's test

the Fluoxetine group and EAE-P groups are shown in Table 5, which demonstrates that EAE-P may be more beneficial to the FUR than Fluoxetine. The variation tendency is shown in Fig. 3.

In summary, EAE-P given in a subchronic treatment regime was beneficial to the behavioral outcome in an animal model of CUMS which induced depression-like behavioral changes.

\section{Effects of EAE-P on the inflammatory cytokines in CUMS-treated rats}

In healthy individuals, there is a regulated balance between pro- and anti-inflammatory cytokines. Altered inflammatory cytokine profiles are often observed in depressed individuals [22].

The tumor necrosis factor-alpha (TNF- $\alpha)$, which is a pro-inflammatory key signaling molecule, might contribute to the pathogenesis of depression because plasma levels of TNF- $\alpha$ and its soluble receptors have been found to be elevated in acutely depressed patients [23], and experimental stimulation of TNF- $\alpha$ production leads to depression-like emotional and cognitive disturbances in humans [24]. In the present study, the mRNA and protein expression level of TNF- $\alpha$ in the hippocampus was measured. Results show significantly higher in depressed subjects compared
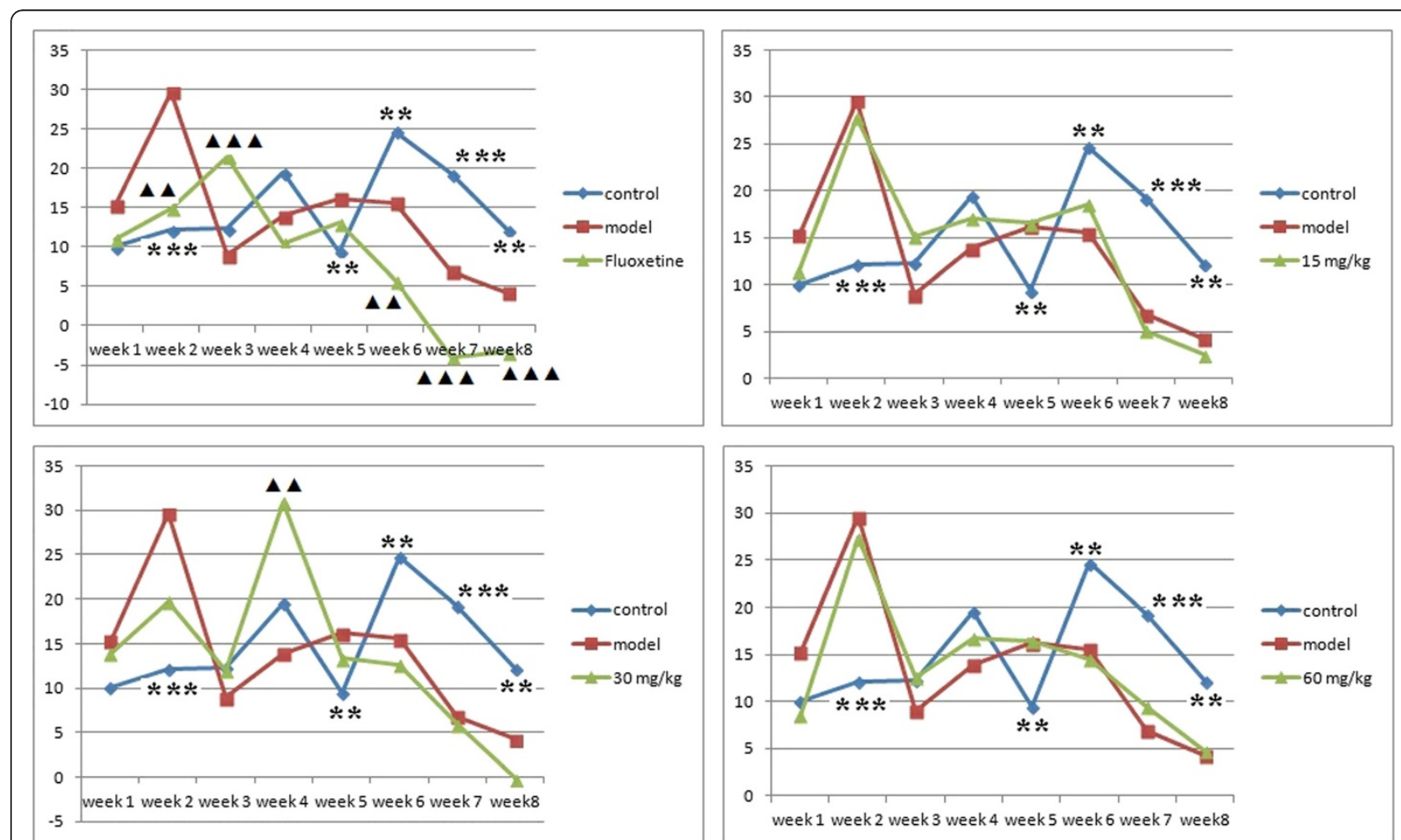

Fig. 2 Effects of EAE-P on the food utilization rate (FUR) in the CUMS-treated rats. Results are expressed as mean \pm S.E.M. $(n=7-9)$. Statistical analysis was performed by analysis of variance (ANOVA) followed by Bonferroni's test. $\boldsymbol{\Delta} \boldsymbol{\Delta} P<0.01$, ${ }^{* * P}<0.01, \boldsymbol{\Delta} \boldsymbol{\Delta} \boldsymbol{\Delta} P<0.001$ and ${ }^{* * * P}<0.001$ compared with model 
Table 5 Comparison of food utilization rate (FUR) between Fluoxetine group and EAE-P groups

\begin{tabular}{|c|c|c|c|c|}
\hline Groups & Week 1 & Week 2 & Week 3 & Week 4 \\
\hline Fluoxetine & $11.03 \pm 3.14$ & $14.95 \pm 4.42$ & $21.39 \pm 1.47$ & $10.45 \pm 0.88$ \\
\hline $15 \mathrm{mg} / \mathrm{kg}$ & $11.44 \pm 1.49$ & $27.78 \pm 3.99 \star$ & $15.13 \pm 1.37 \boldsymbol{\Delta} \boldsymbol{\Delta}$ & $17.07 \pm 1.16$ \\
\hline 30 mg/kg & $13.91 \pm 2.55$ & $19.74 \pm 1.06$ & $12.01 \pm 1.47 \boldsymbol{\Delta} \boldsymbol{\Delta} \boldsymbol{\Delta}$ & $30.88 \pm 0.91 \star \star \star$ \\
\hline $60 \mathrm{mg} / \mathrm{kg}$ & $8.53 \pm 2.29$ & $27.36 \pm 1.69 \star \star$ & $12.61 \pm 1.00 \boldsymbol{\Delta} \boldsymbol{\Delta} \boldsymbol{\Delta}$ & $16.69 \pm 1.37$ \\
\hline Groups & Week 5 & Week 6 & Week 7 & Week8 \\
\hline Fluoxetine & $13.02 \pm 1.09$ & $5.70 \pm 1.56$ & $-3.99 \pm 0.76$ & $-3.37 \pm 0.52$ \\
\hline 15 mg/kg & $16.56 \pm 0.84$ & $18.52 \pm 0.83 \star \star \star$ & $5.15 \pm 0.96 \star \star \star$ & $2.49 \pm 0.89 \star$ \\
\hline 30 mg/kg & $13.39 \pm 1.19$ & $12.64 \pm 1.29$ & $5.92 \pm 1.36 \star \star \star \star$ & $-0.17 \pm 0.54$ \\
\hline 60 mg/kg & $16.41 \pm 0.56$ & $14.53 \pm 1.68 \star$ & $9.37 \pm 1.75 \star \star \star \star$ & $4.71 \pm 0.72 \star \star$ \\
\hline
\end{tabular}

Results are expressed as mean \pm S.E.M. $(n=7-9)$. Statistical analysis was performed by analysis of variance (ANOVA) followed by Bonferroni's test. $\star \star \star$ means the result is higher than Fluoxetine group. $\boldsymbol{\Delta} \boldsymbol{\Delta} \boldsymbol{\Delta}$ means the result is lower than Fluoxetine group. $\boldsymbol{\Delta} p<0.05, \star p<0.05, \boldsymbol{\Delta} \boldsymbol{\Delta} P<0.01, \star \star P<0.01, \boldsymbol{\Delta} \boldsymbol{\Delta} \boldsymbol{\Delta} P<0.001$ and $\star \star \star P<0.001$ compared with model

to controls $(\mathrm{p}<0.001)$ (Fig. 4). Compared with the model group, Fluoxetine markedly $(\mathrm{p}<0.001)$ reduced TNF- $\alpha$ mRNA and protein in the hippocampus. EAE-P treatment at $60 \mathrm{mg} / \mathrm{kg}$ also reduced the mRNA and protein $(\mathrm{p}<0.001)$. However, EAE-P treatment at $30 \mathrm{mg} / \mathrm{kg}$ only reduced the protein expression but not mRNA. This revealed that a high concentration of EAE-P can effectively reverse the action of TNF- $\alpha$.

In recent years, elevated interleukin (IL)- 6 has been reported as a biomarker of depression [25]. IL-10 has been reported to play a role in regulating hypotha-lamicpituitary-adrenal (HPA) axis homeostasis by suppressing adrenocorticotropic hormone-induced steroid production, and diminished IL-10 expression can affect HPA hyperactivity and glucocorticoid resistance seen in depressed patients [26]. In addition, the literature describes concurrent increases in IL-6 and decreases in IL-10 in individuals suffering from major depression. It is hypothesized that higher levels of depressive symptoms would be associated with lower IL-10 and higher IL-6 concentrations, as well as higher IL-6/IL-10 ratios. Also, as shown in Fig. 4, depressed subjects expressed significantly higher IL-6 mRNA and protein expression levels, lower IL-10 and significantly higher IL-6/IL-10 ratios compared to controls. Treatment at different concentrations of EAE-P, compared with the model group, showed significantly lower IL-6 (mRNA: $15 \mathrm{mg} / \mathrm{kg}, \mathrm{p}<0.001$; $30 \mathrm{mg} / \mathrm{kg}, \mathrm{p}<0.05 ; 60 \mathrm{mg} / \mathrm{kg}, \mathrm{p}<0.01$. Protein: $15 \mathrm{mg} / \mathrm{kg}$, $\mathrm{p}<0.001 ; 30 \mathrm{mg} / \mathrm{kg}$ and $60 \mathrm{mg} / \mathrm{kg}, \mathrm{p}<0.01$ ), no significant change in IL-10 and partially significantly lower IL-6/IL-10 ratios (mRNA: $15 \mathrm{mg} / \mathrm{kg}, \mathrm{p}<0.001$. Protein: $15 \mathrm{mg} / \mathrm{kg}, \mathrm{p}<0.05 ; 30 \mathrm{mg} / \mathrm{kg}$ and $60 \mathrm{mg} / \mathrm{kg}, \mathrm{p}<0.01)$. Meanwhile, the Fluoxetine group revealed significantly lower IL-6, significantly higher IL-10 and significantly lower IL-6/IL-10 ratios. These results indicate that the antidepressant-like activation of EAE-P is associated with inflammatory cytokine IL-6 and even IL-6/IL-10 ratios but not IL-10. That is different than the response to Fluoxetine.

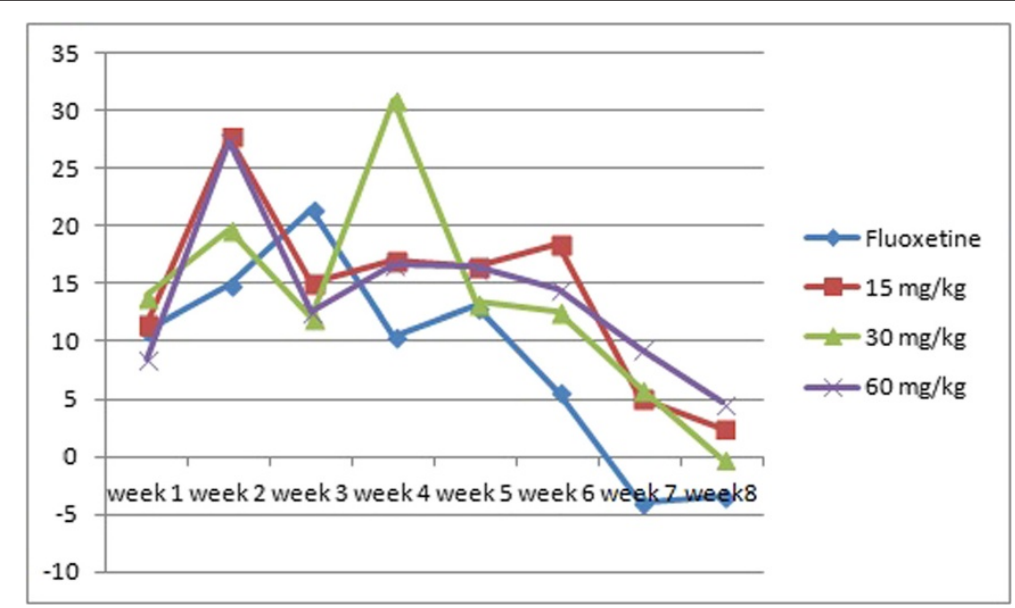

Fig. 3 Comparision of food utilization rate (FUR) variation tendency between Fluoxetine group and EAE-P groups 


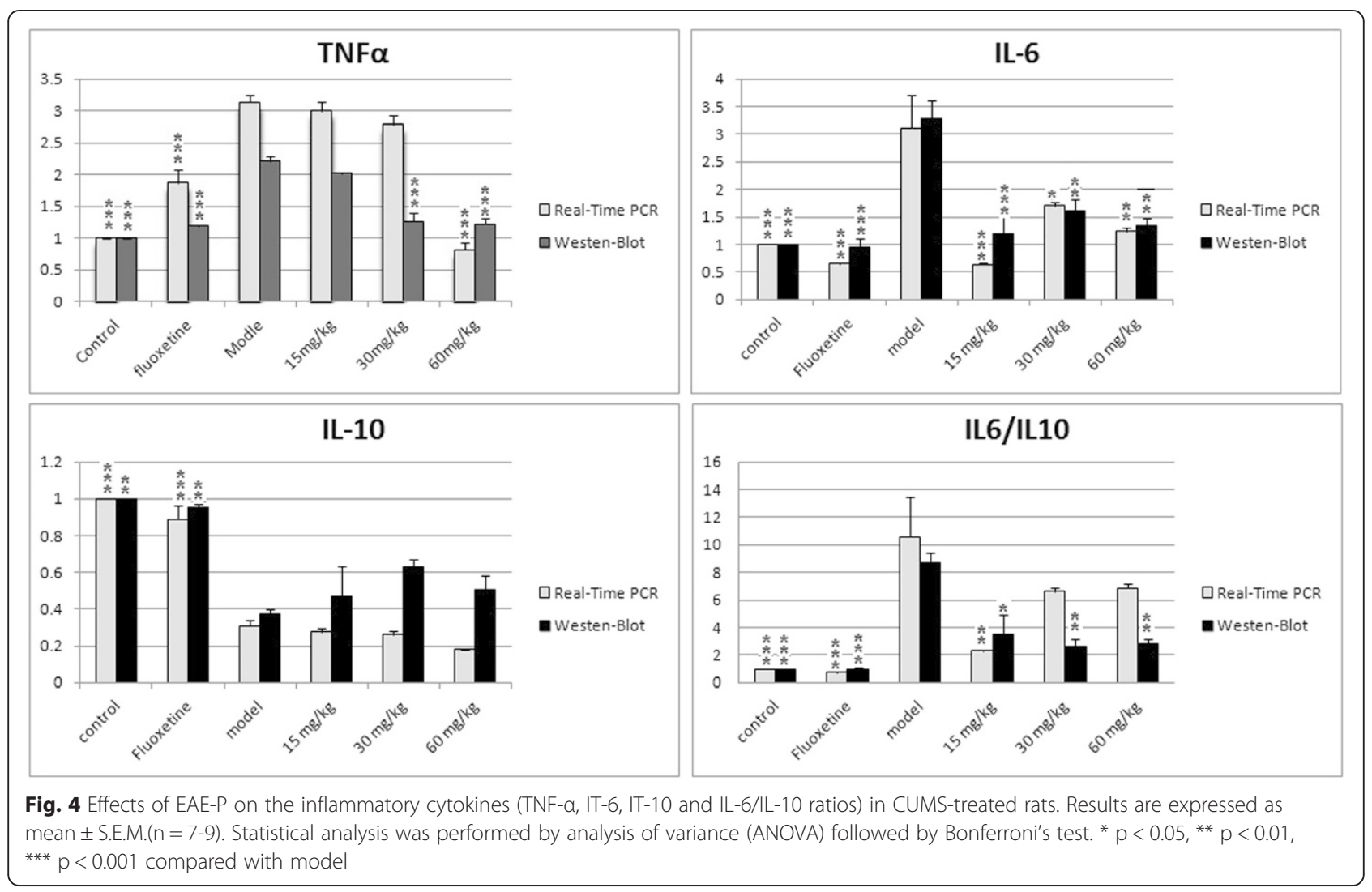

\section{Effects of EAE-P on apoptosis cytokines in CUMS-treated rats}

In addition to inflammatory cytokines, we also investigated the effect of EAE-P on mRNA expression of four apoptosis cytokines, because the apoptosis cytokines have been demonstrated by in vivo imaging studies that patients with major depressive disorders display reduced hippocampal and prefrontal cortex volume [27]. These structural alterations resulted from atrophy and loss of neurons and glia [28]. Activation of apoptotic pathways has been regarded as one of the most important way to cause these structural alterations. P53 is the "gatekeeper" of apoptosis. P53 activity is directed at its transcriptional target $\mathrm{Bax}$ [29], or it translocates to mitochondria to interact with $\mathrm{Bcl}-2$ in a non-transcriptional way [30]. The caspase-dependent mitochondrial way is another approach.

In this study, p53 mRNA was upregulated by the CUMS treatment (Fig. 5). Fluoxetine and $15 \mathrm{mg} / \mathrm{kg}$ of EAE-P decreased hippocampal p53 mRNA expression $(\mathrm{P}<0.001)$ when compared with the model group. This suggests that EAE-P pretreatment may depress p53 to inhibit apoptosis. The Real-Time PCR results of Bax and Bcl-2 showed that pretreatment with EAE-P did not produce pharmacological effects (Fig. 5), with the exception of Bcl-2 at $30 \mathrm{mg} / \mathrm{kg}$. The influence of EAE-P on caspase-3 (Fig. 5) was showed that Fluoxetine and all the different concentrations of EAE-P markedly reduced caspase-3 mRNA expression compared to the control and model $(\mathrm{P}<0.001)$, similar to the results obtained with Fluoxetine. Nevertheless, there is no significant difference in caspase-3 levels between the control and model. Further research is necessary to understand these results.

\section{Effects of EAE-P on the BDNF expression in CUMS-treated rats}

The neurotrophin brain-derived neurotrophic factor (BDNF) is a member of the neurotrophin family and the most wide spread growth factor in the brain. It has diverse functions in the adult brain as a regulator of neuronal survival, fast synaptic transmission and activity-dependent synaptic plasticity [31]. Increasing evidence indicates that BDNF may play a role in the pathophysiology of depression and that antidepressants may, in part, exert their effects through regulation of BDNF. Decreased serum BDNF levels have been reported in depressed patients in several clinical studies, as has the fact that they can be normalized by antidepressant treatment [32]. Recent studies also have reported no effects or even increased BDNF levels in the hippocampus following exposure to chronic stress. It is 


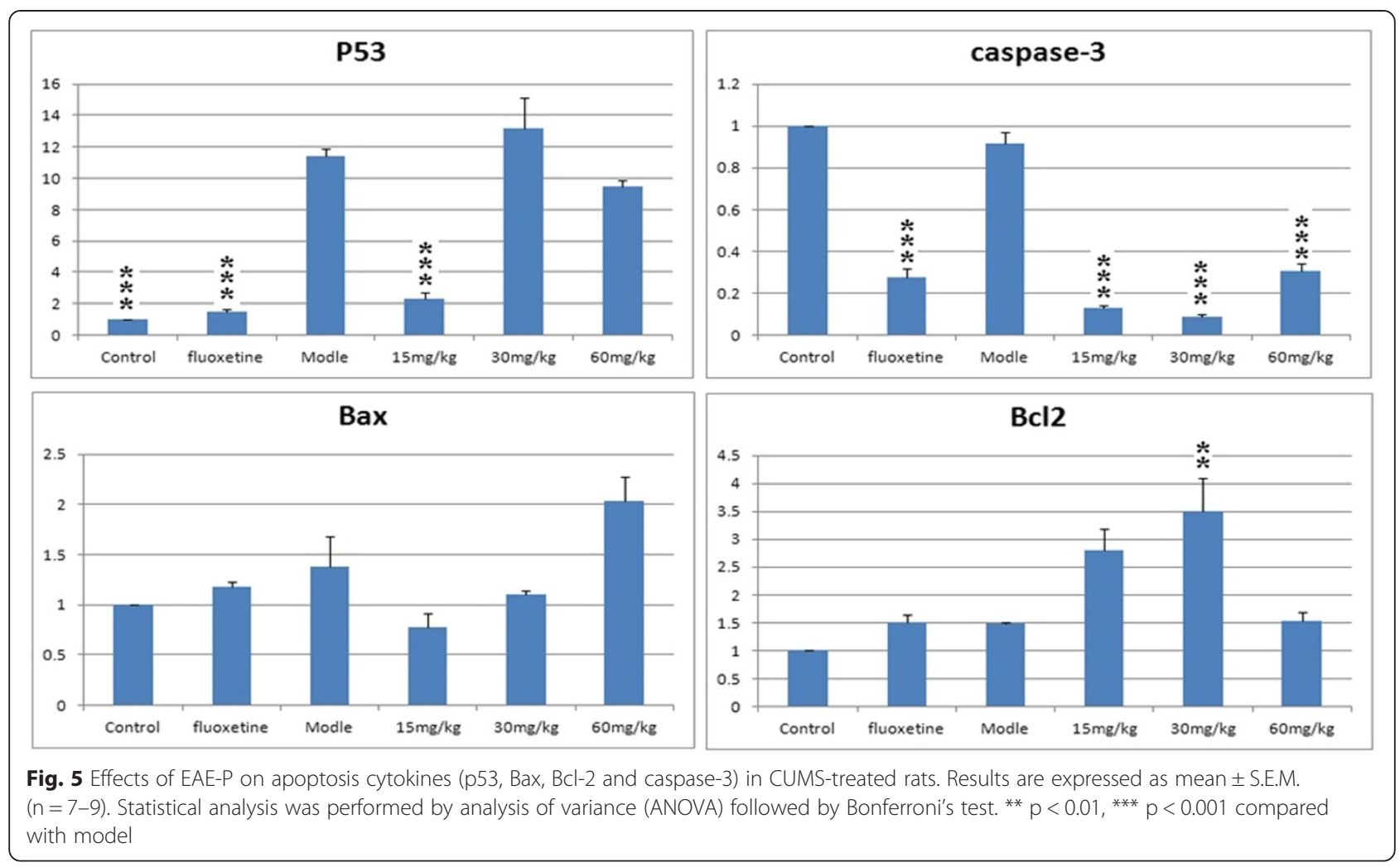

possible that the effects of stress on BDNF mRNA expression in the hippocampus are dependent on several factors such as the type of stressor, the intensity, the duration, the frequency and the number of exposures [33].

The levels of serum BDNF and the BDNF mRNA in the hippocampus are presented in Fig. 6. Although the level of serum BDNF and the BDNF mRNA expression are decreased in the model group compared to the control group, there are no significant differences between them. However, compared with the model group, Fluoxetine markedly $(\mathrm{p}<0.001)$ elevated BDNF mRNA in the hippocampus. EAE-P treatment at 15 and $30 \mathrm{mg} / \mathrm{kg}$ also elevated it $(\mathrm{p}<0.05)$. It has been suggested that BDNF levels may simply not correlate with depressive-like behavior, and a clear correlation between serum and brain BDNF levels still needs to be established. However, Fluoxetine and EAE-P showed up-regulated expression in this study, which needs a further research.

\section{Conclusion}

The results reveal that EAE-P is beneficial to the behavioral outcome of the CUMS model animals, which was not due to an increase in locomotive activity. The
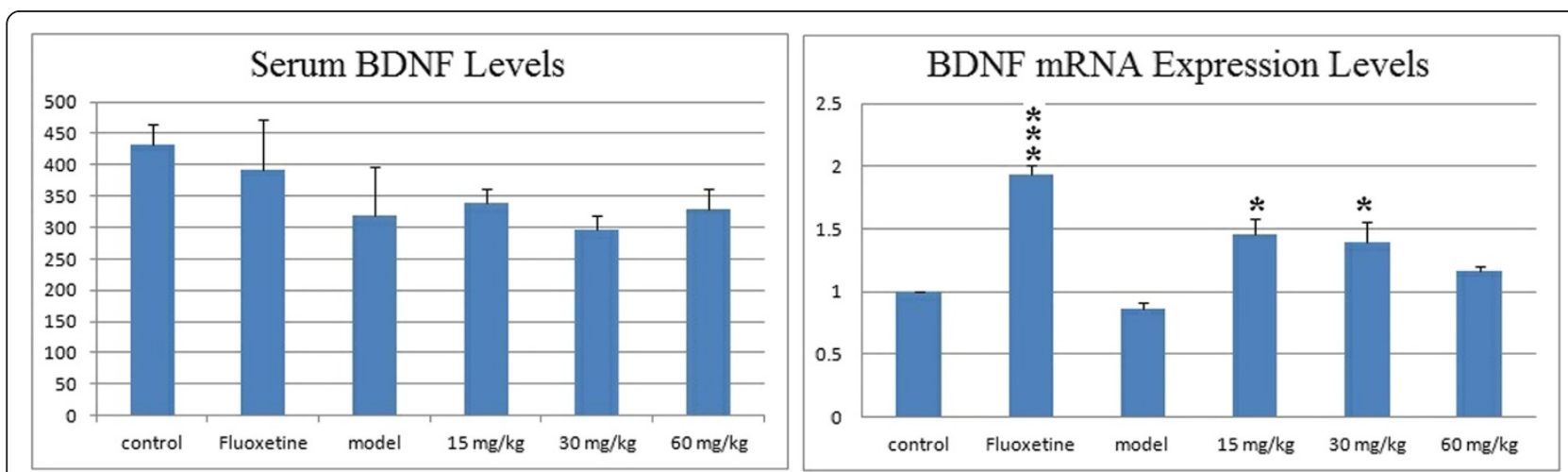

Fig. 6 Effects of EAE-P on Neurotrophin (BDNF) in CUMS-treated rats. Results are expressed as mean \pm S.E.M. $(n=7-9)$. Statistical analysis was performed by analysis of variance (ANOVA) followed by Bonferroni's test. * $p<0.05$, *** $p<0.001$ compared with model 
decreased amounts of inflammatory cytokine IL-6 contributed to the antidepressant-like activation of EAE-P in every dosage group $(15,30,60 \mathrm{mg} / \mathrm{kg})$. However, in the low dosage group, down-regulated apoptosis cytokine p53 is associated with EAE-P effect, but it is inflammatory cytokine TNF- $\alpha$ that is related to the effect of EAE-P in the high dosage group. These suggest that the EAE-P needs to be subdivided for the further mechanism research. Meanwhile, the P53-dependent antiapoptotic effect of EAE-P may not be through Bcl-2 and Bax modulation.

Furthermore, EAE-P showed up-regulated expression of brain-derived neurotrophic factor (BDNF) mRNA and down-regulated apoptosis cytokine caspase-3 mRNA, which was the same change tendency as with Fluoxetine, although there is no significant differences between model and control in Sprague-Dawley rats' CUMS mode.

\section{Abbreviations}

EAE-P: Ethyl acetate extract of $P$. laetispicum; CUMS: Chronic unpredictable mild stress; OFT: Open field test; FUR: Food utilization rate; BDNF: Brain-derived neurotrophic factor; SP: Sucrose preference.

\section{Competing interests}

The authors declare that they have no competing interests.

\section{Authors' contributions}

HX carried out the design of the study, performed the statistical analysis and drafted the manuscript. DJ carried out the experimentation on animals. YK participated in the animal experimentation and its design. XS participated in the design of the study. Hongrui Liu participated in the statistical analysis. HS participated in the animal and molecular experimentation. JC participated in the animal and molecular experimentation. MY participated in the molecular experimentation. $J \mathrm{~L}$ approved the manuscript. SP participated in the design of the study, checked and approved the manuscript. All authors read and approved the final manuscript.

\section{Acknowledgments}

The study was supported and funded by the Ministry of Science and Technology of the People's Republic of China (No. 2009ZX09103-075): Science Committee of Shanghai, China (No. 08DZ1971203); Pudong New District of Shanghai, China (No. PW2008A-7); Beginning Teacher Scientific Research Initial Funding of Fudan University, China. The authors wish to acknowledge Jackie Kelley and Bonnie Watson for their helpful improvement of the English language.

\section{Author details}

${ }^{1}$ School of Pharmacy, Fudan University, Shanghai 201203, China. ${ }^{2}$ Department of Pharmacognosy, College of Pharmacy, Jiamusi University, Jiamusi 154007, China. ${ }^{3}$ Pharmaceutical Preparation Section, Punan Hospital, Shanghai 200127, China.

\section{Received: 25 September 2014 Accepted: 24 June 2015}

Published online: 17 July 2015

\section{References}

1. Engel D, Zomkowski AE, Lieberknecht V, Rodrigues AL, Gabilan NH. Chronic administration of duloxetine and mirtazapine downregulates proapoptotic proteins and upregulates neurotrophin gene expression in the hippocampus and cerebral cortex of mice. J Psychiatr Res. 2013;47:802-8.

2. Linde K, Berner MM, Kriston L. St John's wort for major depression. Cochrane Database Syst Rev. 2008;8(4):CD000448.

3. Dang HX, Chen Y, Liu XM, Wang Q, Wang LW, Jia W, et al. Antidepressant effects of ginseng total saponins in the forced swimming test and chronic mild stress models of depression. Prog Neuro-Psychoph. 2009;33:1417-24.
4. Baum SS, Hill R, Rommelspacher H. Effect of kava extract and individual kavapyrones on neurotransmitter levels in the nucleus accumbens of rats. Prog Neuro-Psychoph. 1998;22:1105-20.

5. Mello JC, Klein T, Longhini R, Bruschi ML. Development and characterization of microparticles from Paullinia cupana var. sorbilis (Guaraná) semipurified extract produced by spray drying. Planta Med. 2013;79:PN61.

6. Kim SH, Han J, Seog DH, Chung JY, Kim N, Park YH, et al. Antidepressant effect of Chaihu- Shugan-San extract and its constituents in rat models of depression. Life Sci. 2005;76:1297-306.

7. Zhonghua Herbals Editorial Committee. Zhonghua Herbals. Shanghai: Shanghai Science Technique Press; 1999. p. 433-4.

8. Yao CY, Wang J, Dong D, Qian FG, Xie J, Pan SL. Laetispicine, an amide alkaloid from Piper laetispicum, presents antidepressant and antinociceptive effects in mice. Phytomedicine. 2009;16:823-9.

9. Xie H, Yan MC, Jin D, Liu JJ, Yu M, Dong D, et al. Studies on antidepressant and antinociceptive effects of ethyl acetate extract from Piper laetispicum and structure - activity relationship of its amide alkaloids. Fitoterapia. 2011;82:1086-92.

10. Willner P, Towell A, Sampson D, Sophokleous S, Muscat R. Reduction of sucrose preference by chronic unpredictable mild stress, and its restoration by a tricyclic antidepressant. Psychopharmacology. 1987;93:358-64.

11. Bekris S, Antoniou S, Daskas S, Papadopoulou-Daifoti Z. Behavioral and neurochemical effects induced by chronic mild stress applied to two different rat strains. Behav Brain Res. 2005;161:45-59.

12. Li J, Zhou Y, Liu BB, Liu Q, Geng D, Weng L, et al. Nobiletin Ameliorates the Deficits in Hippocampal BDNF, TrkB, and Synapsin I Induced by Chronic Unpredictable Mild Stress. Evid-Based Compl Alt. 2013;Article ID 359682:1-11.

13. Campbell S, Macqueen $\mathrm{G}$. The role of the hippocampus in the pathophysiology of major depression. J Psychiatr Neurosci. 2004;29:417-26.

14. Gamaro GD, Prediger ME, Lopes J, Bassani MG, Dalmaz C. Fluoxetine alters feeding behavior and leptin levels in chronically-stressed rats. Pharmacol Biochem Behav. 2008;90:312-7.

15. Cai CC, Yan MC, Xie H, Pan SL. Simultaneous Determination of Ten Active Components in 12 Chinese Piper Species by HPLC. Am J Chinese Med. 2011:39:1043-60.

16. Li LF, Lu J, Li XM, Xu CL, Yang J, Qu R, et al. Antidepressant-like effects of the saponins extracted from Chaihu-jia-longgu-muli-tang in a rat unpredictable chronic mild stress model. Fitoterapia. 2012;83:93-103.

17. Razzoli M, Domenici E, Carboni L, Rantamaki T, Lindholm J, E. Castrén E, et al. A role for BDNF/TrkB signaling in behavioral and physiological consequences of social defeat stress. Genes, Brain and Behavior. 2011;10:424-33.

18. Na XL, Liu XW, Chen WH. Effects of soybean isoflavone on body weight and food utilization rate in ovariectomized rats. Journal of Hygiene Research. 2005;34:432-35.

19. Livak KJ, Schmittgen TD. Analysis of relative gene expression data using real-time quantitative PCR and the 2(-Delta Delta C(T)) Method. Methods. 2001;25:402-8

20. Marcellino D, Roberts DCS, Navarro G, Filip M, Agnati L, Lluis C, et al. Increase in $A(2 A)$ receptors in the nucleus accumbens after extended cocaine self-administration and its disappearance after cocaine withdrawal. Brain Res. 2007;1143:208-20.

21. Zhou YZ, Lu LL, Li ZF, Gao XX, Tian JS, Zhang LZ, et al. Antidepressant-like effects of the fractions of Xiaoyaosan on rat model of chronic unpredictable mild stress. J Ethnopharmacol. 2011;137:236-44.

22. Dantzer R, O'Connor JC, Lawson MA, Kelley KW. Inflammation-associated depression: From serotonin to kynurenine. Psychoneuroendocrinology. 2011;36:426-36

23. Himmerich H, Fulda S, Linseisen J, Seiler H, Wolfram G, Himmerich S, et al. Depression, comorbidities and the TNF-alpha system. Eur Psychiat. 2008;23:421-9.

24. Reichenberg A, Yirmiya R, Schuld A, Kraus T, Haack M, Morag A, et al. Cytokine-associated emotional and cognitive disturbances in humans. Arch Gen Psychiat. 2001;58:445-52.

25. Dowlati Y, Herrmann N, Swardfager W, Liu H, Sham L, Reim EK, et al. A metaanalysis of cytokines in major depression. Biol Psychiatry. 2010;67:446-57.

26. Voorhees JL, Tarr AJ, Wohleb ES, Godbout JP, Mo XK, Sheridan JF, et al. Prolonged Restraint Stress Increases IL-6, Reduces IL-10, and Causes Persistent Depressive-Like Behavior That Is Reversed by Recombinant IL-10. PLOS ONE. 2013;8:e58488.

27. Bremner JD. Structural changes in the brain in depression and relationship to symptom recurrence. CNS Spectrums. 2002;7:129-130. 135-139. 
28. Krishnan $\mathrm{V}$, Nestler EJ. The molecular neurobiology of depression. Nature. 2008:455:894-902.

29. Chipuk JE, Kuwana T, Bouchier-Hayes L, Droin NM, Newmeyer DD, Schuler $M$, et al. Direct activation of Bax by p53 mediates mitochondrial membrane permeabilization and apoptosis. Science. 2004;303:1010-4.

30. Vaseva AV, Moll UM. The mitochondrial p53 pathway. Biochim Biophys Acta. 2009;1787:414-20.

31. Bramham CR, Messaoudi E. BDNF function in adult synaptic plasticity: the synaptic consolidation hypothesis. Prog Neurobiol. 2005;76:99-125.

32. Brunoni AR, Lopes M, Fregni F. A systematic review and meta-analysis of clinical studies on major depression and BDNF levels: implications for the role of neuroplasticity in depression. Int J Neuropsychoph. 2008;11:1169-80.

33. Larsen MH, Mikkelsen JD, Hay-Schmidt A, Sandi C. Regulation of brain-derived neurotrophic factor (BDNF) in the chronic unpredictable stress rat model and the effects of chronic antidepressant treatment. J Psychiatr Res. 2010;44:808-16.

\section{Submit your next manuscript to BioMed Central and take full advantage of:}

- Convenient online submission

- Thorough peer review

- No space constraints or color figure charges

- Immediate publication on acceptance

- Inclusion in PubMed, CAS, Scopus and Google Scholar

- Research which is freely available for redistribution 